\title{
Kendala Struktural dan Kultural Praktek Keterbukaan Informasi Publik di Badan Publik Non-Pemerintah : Studi Kasus PSSI
}

\author{
Narayana Mahendra Prastya \\ Program Studi Ilmu Komunikasi, Fakultas Psikologi dan Ilmu Sosial Budaya, Universitas Islam \\ Indonesia \\ narayana@uii.ac.id
}

\begin{abstract}
This article discuss about case study on how Indonesian Football Association (Indonesian FA) give their respond to do the Public Information Disclosure. Indonesian FA than express their objection to the demand. Indonesian FA choose as the object in this case, as a representative of non-governmental public organization. This article use Indonesian FA statement related to the Public Information Disclosure, that posted on official website www.pssi.org. Then I use frame analysis Robert N.Entman model as a analytical tool to the statement. The results show that there are two factors that cause Indonesian FA objection. First is structural factor that came from the Indonesian Public Disclosure Act and Act related to the management of football federation. The second is cultural factor that non-governmental public organization in Indonesia, in general, not accustomed to public disclosure obligation.
\end{abstract}

Keywords: indonesian footbal association, non-governmental public organization, public information disclosure, sport communication

\begin{abstract}
Abstrak
Tulisan ini mengambil studi kasus bagaimana Persatuan Sepakbola Seluruh Indonesia merespon tuntutan untuk Keterbukaan Informasi Publik. Keputusan Komisi Informasi Pusat (KI Pusat) bahwa PSSI harus menerapkan praktek Keterbukaan Informasi Publik mendapatkan keberatan dari pihak PSSI. Permasalahan pun berbuntut panjang hingga sampai di persidangan tingkat Mahkamah Agung. PSSI dipilih sebagai objek penelitian guna mengkaji bagaimana badan publik non-pemerintah memahami Keterbkaan Informasi Publik. Data dalam tulisan ini menggunakan pernyataan-pernyataan yang disampaikan PSSI melalui website www.pssi.org berkaitan dengan keputusan KI Pusat. Pernyataan tersebut kemudian dianalisis menggunakan framing model Robert N.Entman. Analisis menunjukkan terdapat kendala struktural dan kultural. Faktor struktural datang dari peraturan yang berkaitan dengan PSSI dan peraturan di UU KIP itu sendiri. Sedangkan faktor kultural berkaitan dengan kondisi badan publik non-pemerintah yang tidak terbiasa menghadapi tuntutan keterbukaan informasi.
\end{abstract}

Kata Kunci: badan publik non-pemerintah, keterbukaan informasi publik, komunikasi olahraga, PSSI 


\section{Pendahuluan}

Undang-Undang Nomor 14 tahun 2008 tentang Keterbukaan Informasi Publik (KIP) mewajibkan setiap badan publik, penyelenggara negara, termasuk pemerintah menjalankan kewajiban memenuhi hak masyarakat akan informasi publik. Lingkup Badan Publik meliputi lembaga eksekutif, yudikatif, legislatif, serta penyelenggara negara lainnya yang mendapatkan dana dari Anggaran Pendapatan dan Belanja Negara (APBN) atau Anggaran Pendapatan dan Belanja Daerah (APBD) dan mencakup pula organisasi non-pemerintah, baik yang berbadan hukum maupun yang tidak berbadan hukum, seperti Lembaga Swadaya Masyarakat (LSM), perkumpulan, serta organisasi lainnya yang mengelola atau menggunakan dana yang sebagian atau seluruhnya bersumber dari APBN atau APBD, sumbangan masyarakat, dan/atau luar negeri (PPID Kemkominfo, n.d.)

Pembahasan mengenai praktek KIP pada umumnya mengambil objek pada lembaga-lembaga pemerintah dan penyelenggara negara. Padahal berdasarkan pengertian di atas, ada pula lembaga publik non-pemerintah. Sementara kajian mengenai KIP di badan publik non-pemerintah masih sangat jarang. Oleh karena itu, tulisan ini akan membahas KIP di badan publik non-pemerintah.

Penulis memilih Persatuan Sepakbola Seluruh Indonesia (PSSI) sebagai badan publik non-pemerintah yang dibahas di sini. PSSI masuk kategori tersebut usai Komisi Informasi Pusat menetapkan PSSI sebagai badan publik nonpemerintah pada Desember 2014. Keputusan ini hadir menyusul adanya pengaduan dari komunitas suporter Indonesia, yakni Forum Diskusi Suporter Indonsia (FDSI), terhadap Komisi Informasi. Sebelumya FDSI menuntut PSSI transparan terhadap publik berkaitan dengan pengelolaan keuangan (Komisi Informasi Pusat Republik Indonesia, 2014)

Namun keputusan Komisi Informasi Pusat tersebut justru disambut oleh penolakan dari PSSI. Federasi sepakbola Indonesia tersebut mengajukan keberatan ke Pengadilan Negeri Jakarta Pusat. Usai putusan PN Jakarta Pusat menyatakan PSSI kalah, organisasi yang berdiri 19 April tahun 1930 itu melanjutkan ke kasasi di tingkat Mahkamah Agung. PSSI menjelaskan kasasi tersebut bermaksud meluruskan bahwa PSSI bukanlah badan publik, bukan lembaga pemerintah, dan tidak menerima APBN secara langsung. (Vetriciawizach, 2015)

Mahkamah Agung memutuskan untuk menolak permohonan keberatan PSSI untuk keberatan seluruhnya dan menguatkan putusan Komisi Informasi Pusat RI Nomor 199/VI/KIP-PS-A/2014 tanggal 8 Desember 2014. Keputusan tersebut tertuang dalam Put.No.290/Pdt.Sus/KIP/2-14/PN.JKT.PST, tanggal 18 Februari 2015 (Direktori Putusan Mahkamah Agung, 2015).

Respon PSSI terhadap keputusan Komisi Informasi Publik dapat dilihat sebagai adanya kendala dalam penerapan UU KIP khususnya di lembaga publik non-pemerintah. Kendala tersebut berada dalam tataran struktural dan kultural. Kendala ini terjadi akibat dua faktor, yakni dari internal organisasi itu sendiri dan dari segi peraturannya tentang KIP. 
Di Indonesia, pengakuan hak atas informasi termuat dalam perubahan kedua Amandemen Undang-Undang Dasar 1945 Pasal 28 F, Undang-Undang No.12 tahun 2005, dan sekitar 19 Undang-Undang lain yang secara eksplisit mengakui adanya hak atas informasi. Namun jaminan hak atas informasi ini baru dimuat dalam UU KIP No 14/2008 (Suryani, 2009). Dengan diberlakukannya UU No 14/2008, berbagai masalah transparansi informasi, khususnya yang terikat atau pun dikuasai oleh badan-badan publik, harus menyesuaikan dengan ketentuan yang memberikan kesempatan kepada masyarakat dalam mengakses informasi (Susanto, 2009).

Secara umum tema kajian mengenai KIP di Indonesia adalah mengkritisi UU KIP dari perspektif kebijakan komunikasi, analisis tentang praktek KIP di badan publik, serta kritik terhadap implementasi KIP dengan mengungkapkan hambatan-hambatan yang terjadi. Pada umumnya kajian-kajian tersebut mengambil objek badan publik pemerintah atau penyelenggara negara.

Pasal tentang informasi yang dikecualikan (Bab V pasal 17 sampai dengan pasal 22) dalam UU KIP Nomor 14/2008 menjadi salah satu diskusi dalam kajian KIP. Pasal tersebut dikhawatirkan akan memunculkan keterbukaan maupun kebebasan semu dalam informasi. Akibatnya UU KIP yang sejatinya diharapkan mampu menegakkan pilar demokrasi dalam kehidupan berbangsa dan bernegara, dapat saja tidak mampu mendukung penyelenggaraan pemerintahan yang peduli terhadap pemberantasan korupsi dan pelayanan kepada publik yang lebih baik (Susanto, 2009).

Dari segi pelaksanaan, implementasi UU KIP di Indonesia masih sangat rumit, baik itu dari segi teks Undang-Undang 14/2008 maupun pelaksanaannya. Masih adanya sejumlah pasal "karet", belum selarasnya UU KIP dengan aturan penjelasan di bawahnya, hingga budaya kerja di organisasi pemerintah yang belum sejalan dengan semangat KIP membuat pelaksanaan KIP di Indonesia berjalan lambat (Aritonang, 2011).

Pelaksanaan KIP bergantung pada faktor struktural dan kultural. Faktor struktural mencakup yakni karakteristik pimpinan organisasi, karakteristik internal organisasi, dan karakteristik eksternal organisasi (Poentarie, 2010) dan faktor kultural adalah seberapa familiar organisasi tersebut menjalankan UU KIP (Hermawan, 2014)

\section{Metode Penelitian}

Untuk mengetahui respon PSSI terhadap keputusan KIP, penelitian ini menggunakan metode analisis framing (bingkai). Respon PSSI diperoleh dari pernyataan-pernyataan resmi yang dipublikasikan di website resmi www.pssi.org.

Website resmi organisasi merupakan media komunikasi online yang dapat memuat beragam informasi untuk diketahui khalayak umum. Melalui website perusahaan dapat mencantumkan segala hal yang berkaitan dengan organisasi dan menyertakan kontak yang dapat dihubungi. Website -- dan media berbasis internet lainnya -- memberikan manfaat bagi organisasi untuk dapat menyampaikan klarifikasi atau penjelasan terhadap isu yang menimpa organisasi, secara cepat dan dengan jangkauan khalayak yang luas (Dewa Broto, 2014). 
Melalui website resminya, organisasi tidak hanya dapat memberikan keterangan. Website juga dapat dimanfaatkan organisasi melakukan presentasi diri kepada publik yang bertujuan untuk mencapai citra diri yang diinginkan (Luik, 2011). Terdapat empat pernyataan resmi dari PSSI yang berisi respon terhadap keputusan KI Pusat. Keempat pernyataan tersebut dapat dilihat dalam tabel 1.

Pernyataan tersebut kemudian dianalisis menggunakan metode analisis framing. Metode ini umumnya digunakan untuk menganalisis berita-berita di media massa. Dalam analisis framing, berita dipahami sebagai hasil konstruksi dan pandangan tertentu. Itu sebabnya, realitas yang sama dapat diberitakan secara berbeda-beda di media yang berbeda (Eriyanto, 2002) Tidak hanya berita, pernyataan yang disampaikan oleh organisasi pun juga merupakan sebuah konstruksi atas realitas. Frame dalam tulisan ini dipahami sebagai frame organisasi, yakni frame yang dibuat oleh suatu organisasi untuk mendefinisikan suatu peristiwa atau isu dan bertujuan untuk memnegaruhi opini publik sehingga tercipta citra organisasi yang positif (Kriyantono, 2015).

Tabel 1. Pernyataan PSSI berkaitan dengan Keputusan KI Pusat

\begin{tabular}{|c|c|c|c|c|}
\hline No & Judul Pernyataan & $\begin{array}{c}\text { Narasumber } \\
\text { yang terdapat } \\
\text { dalam } \\
\text { pernyataan } \\
\end{array}$ & $\begin{array}{l}\text { Tanggal } \\
\text { publikasi } \\
\text { dokumen }\end{array}$ & $\begin{array}{l}\text { Tanggal } \\
\text { akses } \\
\text { dokumen }\end{array}$ \\
\hline 1 & $\begin{array}{l}\text { Inilah Sikap PSSI terhadap } \\
\text { Putusan Sidang KIP }\end{array}$ & $\begin{array}{l}\text { Direktur Hukum } \\
\text { PSSI }\end{array}$ & $\begin{array}{ll}8 & \text { Desember } \\
2014 & \end{array}$ & 1 April 2016 \\
\hline 2 & $\begin{array}{lc}\text { Rasionalitas } & \text { Hukum dan } \\
\text { Transparansi } & \text { Pengelolaan } \\
\text { PSSI } & \end{array}$ & $\begin{array}{l}\text { Direktur Hukum } \\
\text { PSSI }\end{array}$ & $\begin{array}{l}12 \text { Desember } \\
2014\end{array}$ & 1 April 2016 \\
\hline 3 & $\begin{array}{l}\text { PSSI Sudah Sangat } \\
\text { Transparan }\end{array}$ & $\begin{array}{l}\text { - Pengurus } \\
\text { Asosiasi } \\
\text { Propinsi PSSi } \\
\text { - Pengurus } \\
\text { federasi } \\
\text { olahraga lain } \\
\text { (Ikatan Pencak } \\
\text { Silat } \\
\text { Indonesia) }\end{array}$ & $\begin{array}{l}13 \text { Desember } \\
2014\end{array}$ & 1 April 2016 \\
\hline 4 & $\begin{array}{l}\text { Ketum PSSI: PSSI } \\
\text { Transparan, Tidak Ada yang } \\
\text { Disembunyikan }\end{array}$ & $\begin{array}{l}\text { Ketua Umum } \\
\text { PSSI }\end{array}$ & 2 Januari 2015 & 1 April 2016 \\
\hline
\end{tabular}

Tulisan ini menggunakan framing model Robert N.Entman. Proses framing menekankan pada proses seleksi dan menonjolkan aspek tertentu dari realitas. Bentuk penonjolan tesebut diantaranya menempatkan aspek informasi yang lebih menonjol dibandingkan yang lain, pengulangan informasi yang dianggap penting, dan pemakaian label (sebutan) tertentu (Eriyanto, 2002). Komponen framing model Robert N. Entman terdapat dalam Tabel 2. 
Tabel 2. Komponen Framing Model Robert N. Entman

\begin{tabular}{ll}
\hline \multicolumn{1}{c}{ Komponen Framing } & \multicolumn{1}{c}{ Penjelasan } \\
\hline Pendefinisian masalah & $\begin{array}{l}\text { Bagaimana suatu peristiwa/isu dilihat? Sebagai apa? } \\
\text { Atau sebagai masalah apa? }\end{array}$ \\
$\begin{array}{l}\text { Memperkirakan masalah atau } \\
\text { sumber masalah }\end{array}$ & $\begin{array}{l}\text { Peristiwa itu dilihat disebabkan oleh apa? Apa yang } \\
\text { dianggap sebagai penyebab dari suatu masalah? Siapa } \\
\text { aktor yang dianggap sebagai penyebab masalah? }\end{array}$ \\
Membuat keputusan moral & $\begin{array}{l}\text { Nilai moral apa yang disajikan untuk menjelaskan } \\
\text { masalah? Nilai moral apa yang dipakai untuk } \\
\text { melegitimasi atau mendelegitimasi suatu tindakan? }\end{array}$ \\
Menekankan penyelesaian & $\begin{array}{l}\text { Penyelesaian apa yang ditawarkan untuk mengatasi } \\
\text { masalah/isu? Jalan apa yang ditawarkan dan harus } \\
\text { ditempuh untuk mengatasi masalah? }\end{array}$ \\
\hline
\end{tabular}

\section{Hasil Penemuan dan Diskusi}

\section{Kronologis PSSI sebagai Badan Publik Non-Pemerintah}

Bagian ini memberikan gambaran bagaimana PSSI kemudian masuk kategori badan publik non-pemerintah. Pasca keputusan Komisi Informasi Publik, timbul penolakan dari PSSI untuk terbuka kepada publik. PSSI menilai dasar hukum KIP mash belum jelas. Selain itu PSSI selalu berdalih bahwa secara hukum PSSI adalah badan hukum privat yang berbentuk perkumpulan dan independen.

Semua berawal dari tuntutan kelompok suporter sepakbola Indonesia yang tergabung dalam Forum Diskusi Suporter Indonesia (FDSI) kepada PSSI untuk transparan soal keuangan. FDSI meminta informasi publik tentang dokumen kontrak dan nilai kontrak antara PSSI dengan Stasiun Televisi (MNC dan SCTV) untuk hak siar timnas U-19 selama gelaran Piala AFF U-19 tahun 2013, Pra Piala Asia U-19 tahun 2013 dan Tur Nusantara U-19 tahun 2014. Juga rincian penerimaan dan penggunaan hak siar timnas senior, Timnas U-23 dan Timnas U19 selama tahun 2012-2014. Termasuk pengelolaan dana hak siar dan sponsorship, seperti berapa jumlah tiket yang telah dicetak PSSI sepanjang penyelanggaraan piala AFF U-19 tahun 2013, Pra Piala Asia U-19 tahun 2013 dan Tur Nusantara U-19 tahun 2014, termasuk rincian kategori tiket. Rincian distribusi keseluruhan kategori tiket yang telah dicetak, pemasukan yang diperoleh PSSI dari penjualan tiket, pemasukan dari sponshorship apparel Timnas Senior, U-23 dan U-19 selama 2012-2014 serta kebijakan yang melatarbelakangi perubahan harga tiket selama pertandingan Piala AFF U-19 tahun 2013, Pra Piala Asia U-19 tahun 2013 dan Tur Nusantara U-19 tahun 2014.

FDSI melayangkan surat tuntutan transparansi kepada pihak PSSI, namun federasi sepakbola Indonesia tersebut tak memberikan respon. Setelah dua kali mengajukan tuntutan dan menemui jalan buntu, FDSI kemudian menggugat ke Komisi Informasi Pusat pada 10 Juni 2014. FDSI melaporkan kepada Komisi Informasi Pusat untuk mengetahui apakah keuangan sebuah federasi boleh diketahui publik atau tidak. Komisi Informasi Pusat memberikan respon pada pertengahan Oktober 2014, melalui surat resmi bernomor 181/IX/KIP-RLS/2014 
Komisi Informasi Pusat melakukan panggilan sidang dengan PSSI selaku termohon dan FDSI selaku termohon. Sidang perdana berlangsung pada 20 Oktober 2014 (FDSI News, 214).

Pada Desember 2014, Komisi Informasi Pusat memutuskan PSSI sebagai badan publik non-pemerintah. Dalam amar putusannya, Majelis Komisioner (MK) Komisi Informasi Pusat mengabulkan semua permohonan dari pemohon FDSI kepada termohon PSSI. MK memutuskan mengabulkan permohonan pemohon untuk seluruhnya. Menyatakan informasi yang dimohon pemohon merupakan informasi publik yang bersifat terbuka, serta memerintahkan termohon untuk memberikan informasi yang diminta pemohon sejak putusan ini berkekuatan hukum tetap (Komisi Informasi, 2014).

PSSI langsung merespon keputusan Komisi Informasi Pusat itu dengan penolakan. Pernyataan disampaikan oleh Aristo Pangaribuan selaku Direktur Hukum PSSI. PSSI berpendapat putusan Komisi Informasi Pusat tidak berdasarkan rasio hukum, oleh karenannya PSSI akan mengajukan langkah hukum keberatan. Keterbukaan bagi PSSI bukanlah hal yang haram dilakukan, sepanjang berdasarkan pada dasar-dasar hukum yang jelas. PSSI pada dasarnya menghargai putusan yang telah dikeluarkan Komisi Informasi Pusat. Namun demikian, PSSI menilai pertimbangan-pertimbangan Komisi Informasi Pusat dalam memutuskan banyak yang melanggar hukum acara dan bahkan melanggar peraturan Komisi Informasi Pusat itu sendiri baik secara material maupun secara formal.

PSSI merasa perlu melakukan langkah hukum keberatan agar tidak menimbulkan kerancuan hukum di dalam pengelolaan organisasi sepakbola di Indonesia. PSSI akan menggunakan haknya untuk mengajukan keberatan sesuai dengan Pasal 47-49 UU KIP dan Peraturan Mahkamah Agung (PERMA) No. 2 tahun 2011 mengenai Tata Cara Penyelesaian Sengketa Informasi Publik di Pengadilan. Dengan diajukannya langkah hukum keberatan tersebut maka putusan tersebut belumlah berkekuatan hukum tetap. PSSI yakin, pertimbanganpertimbangan yang tidak berdasarkan hukum akan diluruskan oleh Pengadilan Negeri di tempat PSSI berdomisili.

Dalam pernyataan terpisah, PSSI menjelaskan seperti apa posisinya secara hukum. PSSI menjelaskan bahwa posisi mereka adalah badan hukum privat yang berbentuk perkumpulan. Sebagai badan hukum privat, PSSI menunjukkan dirinya sebagai anggota federasi sepakbola dunia FIFA. Dengan mengutip aturan di Undang-Undang Sistem Keolahragaan Nasional, pemerintah mewajibkan PSSI menjadi anggota FIFA yang independen. PSSI juga menjelaskan alasan mereka untuk tidak serta merta tunduk kepada keputusan Komisi Informasi Pusat karena: "hubungan yang tercipta antara pemerintah dengan PSSI adalah suatu hubungan horisontal dimana PSSI merupakan mitra kerja pemerintah yang independen dalam melakukan tugas pengelolaan sepakbola". PSSI juga mengkritisi UndangUndang KIP yang mereka nilai tidak jelas dalam mendefinisikan tentang badan publik. (Pangaribuan, 2014)

PSSI cenderung enggan tunduk pada pemerintah Indonesia, karena PSSI berdalih mereka adalah badan yang independen. Tunduk pada pemerintah berarti itu merupakan pelanggaran statuta FIFA karena dalam statuta FIFA mengatur 
adanya larangan terhadap intervensi dari pihak-pihak lain. Pelanggaran itu akan membuat Indonesia mendapatkan sanksi FIFA dan imbasnya akan dikucilkan dari persepakbolaan internasional. PSSI mengatakan bahwa sanksi FIFA dapat menghambat perkembangan sepakbola Indonesia.

Sikap PSSI membuat Menteri Pemuda dan Olahraga, Imam Nahrowi, mengaku tidak yakin apakah dalih pelanggaran Statuta FIFA tersebut memang benar adanya, atau mungkin hanya merupakan tameng PSSI belaka (Detik Sport, 2015). Tak hanya Menpora, tetapi masyarakat Indonesiapun gerah dengan sikap PSSI yang dinilai arogan dan melecehkan kedaulatan Indonesia. PSSI merupakan organisasi yang berbasis di Indonesia, tetapi PSSI tidak mau menuruti ketetapan pemerintah Indonesia yang dikeluarkan berdasarkan hukum yang berlaku (hukum Indonesia). PSSI lebih memprioritaskan FIFA, sehingga mengesankan bahwa PSSI adalah "perwakilan" FIFA yang ada di Indonesia.

Namun keputusan Komisi Informasi Pusat tersebut justru disambut oleh penolakan dari PSSI. Federasi sepakbola Indonesia tersebut mengajukan keberatan ke Pengadilan Negeri Jakarta Pusat. Usai putusan PN Jakarta Pusat menyatakan PSSI kalah, PSSI melanjutkan ke kasasi di tingkat Mahkamah Agung. Direktur hukum PSSI, Aristo Pangaribuan menyatakan bahwa kasasi tersebut bermaksud meluruskan bahwa PSSI bukanlah badan publik, bukan lembaga pemerintah, dan tidak menerima APBN secara langsung. (Vetriciawizach, 2015)

Dalam keterangan dari MA, PSSI mengajukan enam hal dalam kasasi mereka, yakni: (1) jangka waktu melakukan permohonan ke Komisi Informasi Pusat telah lewat waktu; (2) Putusan Komisi Informasi Pusat telah salah dalam mencantumkan identitas pemohon; (3) Proses persidangan yang melanggar azazazaz hukum acara; (4) Komisi Informasi Pusat tidak melaksanakan kewajibannya untuk melakukan proses mediasi terlebih dahulu; (5) Alat-alat bukti yang digunakan sebagai dasar putusan tidak memenuhi standar pembuktian; (6) Bahwa pertimbangan hukum menentukan pemohon keberatan sebagai badan publik non pemerintah tidak disertai dengan dasar hukum (Direktori Putusan Mahkamah Agung, 2015).

Dalam perkembangan selanjutnya, MA memutuskan menolak permohonan keberatan PSSI untuk keberatan seluruhnya. Keputusan tersebut tertuang dalam Put.No.290/Pdt.Sus/KIP/2-14/PN.JKT.PST, tanggal 18 Februari 2015, tentang Kasasi PSSI atas Keputusan Informasi Pusat. (Direktori Putusan Mahkamah Agung, 2015).

\section{Analisis Framing Pernyataan PSSI}

Di bagian ini penulis akan menyajikan hasil analisis secara umum terhadap empat pernyataan resmi PSSI berkaitan dengan keputusan Komisi Informasi Pusat. Analisis yang disajikan di sini sudah mencakup seluruh pernyataan resmi, tidak per judul pernyataan.

PSSI melakukan frame terhadap isu, tujuannya adalah mempengaruhi interpretasi publik atas suatu isu agar sama dengan interpretasi organisasi. Dalam isu pasti akan timbul pro dan kontra, dan di dalam isu tersebut dapat dijelaskan dalam berbagai pilihan istilah (interpretasi) oleh pihak-pihak yang berbeda yang 
saling bersaing, agar interpretasi mereka terhadap problem tersebut dianggap sebagai kebenaran (Kriyantono, 2015). Cara PSSI membingkai pernyataan dikelompokkan menjadi empat bagian berdasarkan komponen framing Robert $\mathrm{N}$ Entman.

Pendefinisian masalah. PSSI selalu mengklaim bahwa sudah transparan, sudah terbuka. PSSI juga menjelaskan tentang status hukum organisasi mereka yang merupakan badan privat yang menjadi anggota FIFA, mempunyai tata cara pengelolaannya sendiri. Sebagai badan hukum privat, maka PSSI dalam pengelolaannya mempunyai prinsip-prinsip pengelolaan sendiri sebagaimana ditentukan oleh statuta dan regulasi PSSI. Permasalahan keterbukaan informasi ini disebabkan karena tindakan Komisi Informasi Pusat yang tidak sesuai UU KIP dan peraturan yang berkaitan dengan KIP juga masih belum jelas. Itu sebabnya, PSSI tidak menuruti keputusan Komisi Informasi Pusat dan mempermasalahkan dari jalur hukum.

Memperkirakan masalah atau sumber masalah. Dari keempat pernyataan resmi tersebut, dua pernyataan resmi dengan jelas menyebutkan bahwa penyebab masalah ini adalah keputusan Komisi Informasi Pusat dan UU KIP. PSSI menganggap bawa keputusan Komisi Informasi Pusat tidak memiliki rasionalitas hukum, dan dalam proses memutuskan tersebut, Komisi Informasi Pusat melakukan pelanggaran terhadap UU KIP itu sendiri. Sedangkan dari UU KIP, PSSI menilai masih memiliki kelemahan.

Membuat keputusan moral. Berkaitan dengan transparansi, PSSI menyatakan menghargai tuntutan transparansi keuangan yang dilontarkan oleh sebagian suporter, karena menurut PSSI organisasi sepakbola tanpa suporter tidak akan bisa berjalan. Suporter adalah salah satu stakeholder PSSI yang paling penting. Keterbukaan bagi PSSI bukanlah barang haram. PSSI beberapa kali menampilkan kalimat "sangat terbuka untuk publik" dalam pernyataannya. Dalam kalimat ini ada dua kata yang menerangkan posisi PSSI yakni menghargai tuntutan keterbukaan, dan sebagian suporter (keterangan: cetak tebal oleh penulis). PSSI bermaksud menyatakan bahwa mereka memperhatikan tuntutan tersebut. Tetapi di sisi lain, yang menyuarakan tuntutan tersebut tidak semua suporter di Indonesia

Kemudian dari sisi peraturan, PSSI menyatakan bahwa masih banyak kerancuan hukum di Indonesia berkaitan dengan transparansi. Tidak hanya pada sepakbola, tetapi juga dalam pengelolaan olahraga di Indonesia pada umumnya, yang menjadi sasaran kritik PSSI adalah putusan Komisi Informasi Pusat maupun UU No. 3 tahun 2005 mengenai Sistem Keolahragaan Nasional (UU SKN) yang tidak dapat memberikan penjelasan yang cukup. Posisi PSSI sebagai organisasi yang privat dan independen dijamin oleh UU SKN 3/2005. Pemerintah Indonesia melalui UU SKN bukan hanya mengakui tetapi juga mewajibkan PSSI untuk menjadi anggota FIFA yang independen. Hubungan yang tercipta antara pemerintah dengan PSSI adalah suatu hubungan horisontal dimana PSSI merupakan mitra kerja pemerintah yang independen dalam melakukan tugas pengelolaan sepakbola. UU KIP juga tidak memberikan konsep mengenai keterbukaan secara jelas. 
PSSI menyebut pasal-pasal yang dilanggar Komisi Informasi Pusat antara lain Pasal 1867 Kitab UU Hukum Perdata dan 165 HIR yang mengatakan alat bukti artikel di media massa tidak dapat menjadi dasar untuk melakukan pertimbangan hukum. Tindakan Komisi Informasi Pusat melakukan penafsiran terhadap status PSSI juga melanggar UU karena Komisi Informasi Pusat bukanlah badan peradilan yang memegang kekuasaan yudikatif, sehingga tidak mempunyai hak untuk menafsirkan peraturan perundang-undangan, seperti menyatakan PSSI "menerima" dana dari APBN tanpa mengindahkan sistematika pertanggungjawaban dana APBN sebagaimana yang sudah dijelaskan PSSI sebagai termohon. Berkaitan dengan penafsiran, PSSI menyebut tindakan Komisi Informasi Pusat sebagai "nyata-nyata melanggar hukum" (keterangan: cetak tebal oleh penulis).

Soal pendanaan, PSSI sendiri sebenarnya sama dengan PB-PB cabang olahraga lainnya yang sumber dananya justru lebih banyak dari pengurusnya sendiri. Sedangkan yang dari pemerintah jumlahnya sedikit. PSSI juga memberikan keterangan yang menggambarkan kondisi serupa yang dialami federasi/pengurus besar cabang olahraga lain, dalam hal ini pencak silat.

Menekankan penyelesaian. Persoalan transparansi harus diikuti dengan rasionalitas hukum yang jelas. Pemerintah perlu menetapkan suatu mekanisme hubungan hukum yang jelas sehingga tidak terjadi kerancuan hukum dalam pengelolaan olahraga di Indonesia. Dengan dasar hukum yang jelas, niscaya tranparansi dan akuntabilitas PSSI akan berjalan dan akhirnya cita-cita membangun sebuah "perabadan sepakbola" akan terwujud.

Dalam membahas transparansi setidaknya perlu mengacu pada tujuh kerangka hukum: UU SKN dan peraturan pelaksanaannya, Kitab UU Hukum Perdata, Peraturan Menteri Hukum dan HAM no 6/2014 mengenai pengesahan perkumpulan, UU no. 17/2003 mengenai Keuangan Negara, UU no 1 tahun 2004 mengenai Perbendaharaan Negara, Peraturan Pemerintah no. 45/2013 mengenai Tata Cara Pelaksanaan APBN dan Peraturan Pemerintah no. 10/2011 mengenai Penerimaan Hibah dari Luar Negeri. Karena "kunci" dari badan publik adalah menjalankan tugas-tugas pemerintahan serta mendapatkan dana dari negara, baik yang berasal dari APBN maupun APBD. Kajian seperti inilah yang menurut PSSI tidak dilakukan oleh Komisi Informasi Pusat. Mengenai kewajiban untuk mengekspos laporan keuangan, PSSI hanya wajib melaporkan keuangan yang sumber dananya dari pemerintah, kepada Menpora. Tidak keuangan keseluruhan. Rangkuman mengenai frame pernyataan PSSI dapat dilihat di tabel 3.

Resistensi PSSI terhadap keputusan Komisi Informasi Pusat untuk melakukan Keterbukaan Informasi Publik menunjukkan adanya kendala yakni struktural dan kultural. Titik pijakan struktur adalah terlebih dahulu pemerintah menyiapkan infrastruktur (teknologi, alat, pengetahuan) barulah kemudian dibentuk struktur (pejabat pengelola/penanggungjawab) untuk mengelolanya dan kultur mengikutinya (Alwajih, 2014).

Pembahasan tentang struktur dan kultur menyangkut dua pihak, yakni dari PSSI dari UU KIP itu sendiri. Dari faktor PSSI, organisasi tersebut memang menunjukkan kecenderungan resistensi yang kuat untuk dapat terbuka kepada publik. PSSI terkesan memandang desakan agar terbuka kepada publik sebagai 
sebuah krisis, sebagai sebuah ancaman. Hal ini terlihat dari pernyataan-pernyataan yang disampaikan PSSI dalam situs resminya yang bernada menolak ketetapan pemerintah dan justru balik mengecam pihak lain.

Tabel 3. Frame Pernyataan PSSI berkaitan dengan Keterbukaan Informasi

\begin{tabular}{ll}
\hline Komponen Framing & \multicolumn{1}{c}{ Pernyataan PSSI } \\
\hline Pendefinisian masalah & PSSI merupakan organisasi privat, independen, dan \\
& memiliki prinsip-prinsip pengelolaan sendiri sesuai \\
& statuta PSSI \\
- & PSSI mempermasalahkan keputusan Komisi Informasi \\
& Pusat ke jalur hukum, karena keputusan tersebut tidak \\
& memiliki rasionalitas hukum dan ada beberapa \\
& pelanggaran dalam proses pengambilan keputusan
\end{tabular}

Memperkirakan masalah atau sumber masalah Membuat keputusan moral

Menekankan penyelesaian
Komisi Informasi Pusat, UU KIP

- PSSI menghargai tuntutan untuk transparan dari supporter

- Banyak kerancuan hukum berkaitan dengan pengelolaan olahraga di Indonesia, tidak hanya sepakbola

- Komisi Informasi Pusat melakukan banyak pelanggaran dalam mengeluarkan terkait tuntutan transparansi PSSI

- Sebagian besar dana dari PSSI bukan dari pemerintah

- Untuk memahami transparansi perlu proses pemahaman yang sangat detil, dengan merujuk pada tujuh kerangka hukum yang lain

- Pemerintah perlu menetapkan dasar hukum yang jelas agar PSSI akuntabel

- PSSI hanya perlu melaporkan dana dari pemerintah, tidak keseluruhan dana yang mereka peroleh

Dalam menyampaikan argumen PSSI selalu berlindung di balik alasan mematuhi Statuta FIFA. PSSI menyatakan bahwa pengabdian utama mereka adalah pada FIFA. Memang dalam beberapa hal, PSSI akan menuruti aturan pemerintah. Tetapi ketika peraturan pemerintah itu bertentangan dengan aturan FIFA, maka PSSI menuruti FIFA. Apabila menuruti pemerintah, maka hal tersebut merupakan intervensi pihak ketiga yang sangat dilarang dalam aturan FIFA. Jika itu terjadi, maka sanksi FIFA akan turun.

Dari kacamata hukum, argumen PSSI itu memiliki dasar yang kuat. Menurut Pandjaitan (2011), pemahaman bahwa negara memiliki kekuasaan untuk menghukum dan memaksa sesuai aturan yang berlaku (di negara tersebut) tidak relevan untuk diterapkan dalam konteks federasi olahraga dunia. Kasus seperti ini dapat dijelaskan dengan dasar Teori Hukum Kedaulatan Pluralis, yang membahas hubungan antara negara (state) dengan pasar (market) dan masyarakat sipil (civil society). 
Dalam konteks tersebut maka PSSI, AFC (federasi sepakbola Asia) dan FIFA dapat disebut sebagai civil society dan market sekaligus; dan pemerintah Indonesia sebagai state. Itu sebabnya pemerintahan sebuah negara perlu mengakui dan memberikan kesempatan kepada otoritas FIFA, AFC, dan PSSI sebagai civil society --yang dapat membentuk market sendiri-- untuk mengelola dan menyelenggarakan kompetisi sepakbola profesional, serta penyelesaian sengketa sepakbola profesional yang ditimbulkannya (Pandjaitan, 2011).

Peraturan dari FIFA merupakan kendala struktural yang dihadapi oleh PSSI sehingga mereka terkesan sulit untuk menuruti 100 persen keputusan pemerintah. PSSI juga sulit untuk menuruti opini masyarakat yang menginginkan organisasi tersebut tunduk pada negara. Namun dari FIFA sendiri sebenarnya meminta anggotanya untuk bersikap terbuka berkaitan dengan laporan keuangan. FIFA dalam profil organisasi yang tercantum dalam website resminya menyatakan bahwa sebagai badan pengelola sepakbola dunia, FIFA sangat berkomitmen terhadap praktek prinsip-prinsip dari tata kelola yang baik (good governance), transparansi, dan nol toleransi terhadap tindakan-tindakan yang menyalahi aturan-baik itu dalam konteks olahraga atau konteks lain berkaitan dengan asosiasi/federasi sepakbola (FIFA, n.d.). Dari sini juga perlu dikritisi, bahwa menuruti aturan FIFA mungkin hanya dalih semata dari PSSI.

Kendala struktural kedua adalah dari segi UU KIP itu sendiri. Salah satu gugatan PSSI adalah mengenai definisi Badan Publik Non Pemerintah. Memang, dalam konteks hukum, keberatan PSSI tersebut telah mentah dengan penolakan kasasi dari MA. Tetapi dari sisi lain penolakan tersebut menunjukkan bahwa masih ada kekurangan dalam pasal-pasal di UU KIP.

Kendala struktural berkaitan dengan kendala kultural. Secara struktur, Komisi Informasi Pusat sudah memiliki UU serta lembaga yang bertugas untuk mengawasi jalannya kebijakan tersebut. Tetapi secara kultural hal tersebut belum terbentuk. Organisasi-organisasi yang bukan badan pemerintah, terkesan tidak terbiasa ketika harus mengikuti hal-hal yang berkaitan dengan KIP, terutama mengenai keuangan. Memang, batas pengertian "badan publik" di UU KIP memang masih mengandung persoalan ketika dipraktekkan ke lembaga nonpemerintah karena lembaga-lembaga tersebut tidak terbiasa dengan KIP (Hermawan, 2014).

Belum terbentuknya kultur keterbukaan informasi di lembaga publik nonpemerintah akibat struktur (aturan) yang belum rinci. Masih ada sejumlah pasal yang bisa multitafsir, pasal karet, belum padu-nya antara penjelasan dengan pasalpasal di UU membuat pelaksanaan UU KIP di Indonesia masih belum sempurna.

Kendala kultural lain adalah berkaitan dengan budaya organisasi. Sebuah organisasi pasti memerlukan budaya sebagai bagian dari operasional organisasi tersebut. Budaya organisasi melekat dalam diri anggota organisasi saat mereka melakukan kegiatannya (Silintowe dan Pramudita, 2016). Budaya organisasi yang melekat selama ini adalah, PSSI memandang diri mereka sebagai organisasi yang hanya menginduk pada federasi sepakbola dunia, FIFA. Artinya, untuk tata kelola organisasi, itu harus mengacu pada aturan FIFA. Pemerintah dapat berperan dalam pengembangan sepakbola namun dalam bidang lain seperti penyediaan infrastruktur (lapangan, stadion, izin pertandingan, dll). 
Untuk membentuk kultur tersebut, tidak semata ditentukan dari infrastruktur dan struktur (Alwajih, 2014). Dari pihak lembaga publik nonpemerntah pun juga perlu memiliki keinginan untuk berubah. Keterbukaan Informasi Publik merupakan hal baru bagi organisasi non-publik. Guna mengadopsi hal-hal baru tersebut, organisasi bergantung pada karakteristik pimpinan organisasi, karakteristik internal struktur organisasi, dan karakteristik eksternal organisasi (Poentarie, 2010).

Guna kepentingan penelitian ini, maka yang akan dibahas adalah karakteristik pimpinan organisasi dan karakteristik eksternal organisasi. Karakteristik kepemimpinan adalah sikap pemimpin pada organisasi untuk melakukan perubahan dalam organisasi yang dipimpinnya. Sementara karakteristik eksternal organisasi berkaitan dengan tingkat di mana anggota suatu sistem terhubung, terpengaruh oleh individu lain yang berada di luar sistem.

Karakteristik pimpinan internal di PSSI, melalui pernyataan-pernyataan yang disampaikan cenderung menolak segala bentuk campur tangan pemerintah, meski hal tersebut juga demi perbaikan PSSI. Pasalnya campur tangan pemerintah (atau pihak ketiga yang lain) merupakan pelanggaran terhadap Statuta PSSI dan Statuta FIFA yang dapat berujung sanksi. Hal ini berkaitan dengan karakteristik eksternal organisasi, di mana PSSI secara hukum merupakan badan hukum privat yang berstatus sebagai mitra, bukan bawahan dari pemerintah.

\section{Simpulan}

KIP merupakan hal yang penting. Selain informasi merupakan hak dasar/hak asasi manusia, KIP juga dapat menghadirkan transparansi yang pada akhirnya semakin mendorong partisipasi masyarakat dalam pembangunan. Logikanya, semakin banyak masyarakat tahu tentang informasi tentang hal-hal yang berkaitan dengan hajat hidup mereka entah itu kebijakan maupun anggaran maka semakin mereka ingin berpartisipasi, minimal sebagai pengawas kinerja aparat-aparat negara yang mengurus mereka (Aritonang, 2011).

Berkaitan dengan penerapan KIP di Indonesia, strukturnya sudah ada dalam bentuk aturan dan lembaga regulator (Komisi Informasi). Namun faktanya, praktek tersebut masih sulit untuk dipraktekkan-dalam konteks tulisan ini-untuk lembaga publik non-pemerintah. Kesulitan itu terjadi karena secara kultur, lembaga tersebut masih belum terbiasa dengan tuntutan transparansi keuangan. Karena belum terbiasa, munculah keberatan, bahkan hingga penolakan untuk melaksanakan seperti yang terjadi dalam kasus PSSI.

Idealnya, sebelum ada struktur, pemerintah perlu mempersiapkan infrastruktur, misal berupa pengetahuan. Sosialiasi pengetahuan kepada lembagalembaga publik non-pemerintah tentang pelaksanaan KIP perlu dilakukan. Apabila memiliki pengetahuan, lembaga publik non-pemerintah bisa lebih siap ketika ada tuntutan melaksanakan KIP.

Tulisan ini memiliki keterbatasan karena sumber data hanya menggunakan pernyataan resmi PSSI yang disampaikan melalui website. Selain itu keterbatasan penelitian ini hanya mengungkap kejadian yang berlangsung di kepengurusan PSSI yang aktif di media tahun 2014- 2015. Guna penelitian selanjutnya, penulis 
memberikan saran beberapa tema. Pertama adalah melakukan wawancara dengan pihak PSSI mengenai bagaimana cara mereka mempraktekkan KIP dan cara pandang mereka terhadap arti keterbukaan informasi itu sendiri. Kedua, dapat melakukan penelitian sejenis di badan publik non-pemerintah yang lain

\section{Ucapan Terima Kasih}

Penulis mengucapkan terima kasih kepada Program Studi Ilmu Komunikasi, Fakultas Psikologi dan Ilmu Sosial Budaya, Universitas Islam Indonesia yang telah memberikan dukungan dalam penulisan artikel ini.

\section{Daftar Pustaka}

Alwajih, Ahmad. (2014). Dilema E-Democracy di Indonesia: Menganalisis Relasi Internet, Negara, dan Masyarakat. Jurnal Komunikasi, Volume 8, Nomor $2,139-152$.

Aritonang, Agusly Irawan. (2011). Kebijakan Komunikasi di Indonesia: Gambaran Implementasi UU No.14 tahun 2008 tentang Keterbukaan Informasi Publik. Jurnal Komunikasi ASPIKOM, Volume 1, No 3, 261278.

Detik Sport. (2015, Januari 20). Menpora Menduga Statuta FIFA jadi Alat Menakut-takuti Supaya PSSI Tak Diusik. April 01, 2016. http://sport.detik.com/sepakbola/read/2015/01/20/214253/2809010/76/me npora-menduga-statuta-fifa-jadi-alat-menakuti-takuti-supaya-pssi-takdiusik

Dewa Broto, Gatot S. (2014). The PR: Tantangan Public Relations di Era Keterbukaan Informasi. Jakarta: Gramedia Pustaka Utama.

Direktori Putusan Mahkamah Agung. (2015, Februari 18). Keputusan Mahkamah Agung nomor: Put.No.290/Pdt.Sus/KIP/2-14/PN.JKT.PST. April 10, 2016.

http://putusan.mahkamahagung.go.id/putusan/downloadpdf/675c08424b3a 6fb6455469399c92e4fe/pdf

Eriyanto. (2002). Analisis Framing: Konstruksi, Ideologi dan Politik Media. Yogyakarta: LkiS.

FDSI News. (2014, Oktober 16). Fokus: Keuangan PSSI Tidak Transparan, Suporter Menggugat dan Panggilan Sidang KIP. April 01, 2016. http://www.fdsinews.com/fokus-keuangan-pssi-tidak-transparan-suportermenggugat-dan-panggilan-sidang-kip/

Fifa. (n.d.). Governance Reforms. Maret 31, 2016. http://www.fifa.com/aboutfifa/who-we-are/the-fifa-structure.html

Hermawan, Anang. (2014). Membangun Kebijakan Keterbukaan Informasi Publik Era Pemerintahan 2014-2019. Dalam Sri Sediyaningsih (Ed.). Masa Depan Komunikasi, Masa Depan Indonesia:Tata Kelola Informasi. Jakarta: Ikatan Sarjana Komunikasi Indonesia (ISKI). 
Komisi Informasi Pusat (2014, Desember 9). KIP Perintahkan PSSI Buka Informasi Publik. Januari 2015. http://www.komisiinformasi.go.id/news/view/kip-perintahkan-pssi-bukainformasi-publik

Kriyantono, Rahmat. (2015). Teori Public Relations Perspektif Barat dan Lokal: Aplikasi Penelitian dan Praktik. Jakarta: Kencana Prenada Media Group.

Luik, Jandi. (2011). Media Sosial dan Presentasi Diri. Dalam Fajar Junaedi (Ed.). Komunikasi 2.0: Teoritisasi dan Implikasi. Yogyakarta: Penerbit Buku Litera, ASPIKOM, dan Perhumas BPC Yogyakarta.

Pandjaitan, Hinca IP. (2011). Kedaulatan Negara vs Kedaulatan FIFA dalam Kompetisi Sepakbola Profesional untuk Memajukan Kesejahteraan Umum. Jakarta: Gramedia Pustaka Utama.

Pangaribuan, Aristo. (2014, Desember 12). Rasionalitas Hukum dan Transparansi Pengelolaan PSSI. April 2016. http://pssi.org/in/read/PSSI/Rasionalitas-Hukum-dan-TransparansiPengelolaan-PSSI-6180

Poentarie, Emmy. (2010). Kesiapan Lembaga Publik Negara dalam Impelemtasi UU No 14 Tahun 2008. Jurnal IPTEK-KOM, Volume 12, Nomor 1, 2950 .

PPID Kemkominfo (n.d.). Badan Publik. Januari 19, 2015. http://ppid.kominfo.go.id/badan-publik/

Silintowe, Yunita Budi Rahayu., \& Pramudita, Margaretha Cahya Christy. (2016) Komunikasi Bisnis Lintas Budaya Sekretaris Pada Atasan (Studi Pada Alila Hotel Solo). Jurnal Komunikasi Universitas Tarumanagara, Vol.8, No.2, 147-158.

Suryani, Tanti Budi. (2009). Peran Praktisi Humas Badan Publik dalam Upaya Mewujudkan Kebebasan Informasi bagi Publik. Dalam Wisnu Martha Adiputra (Ed.). Berkawan dengan Media : Literasi Media untuk Praktisi Humas.. Yogyakarta: PKMBP dan TIFA Foundation.

Susanto, Eko Harry. (2009). Undang-undang Keterbukaan Informasi Publik dan Penyelenggaraan Pemerintahan. Jurnal Komunikator, Vol.1, No.2, 123131.

Vetriciawizach. (2015, April 23). PSSI Ajukan Kasasi ke Mahkamah Agung. CNN Indonesia. April 2016. http://www.cnnindonesia.com/olahraga/20150423170251-142-48818/pssiajukan-kasasi-ke-mahkamah-agung/ 